\title{
The Self in Legal Procedure: Oath-Taking as Individualism in Norwegian Medieval Law
}

\begin{abstract}
This article examines an institution in Norwegian medieval law wherein a defendant in a case could swear an individual oath in order to unilaterally dismiss the charges against them. By analyzing three law books dating to the late twelfth, the mid-thirteenth, and the late-thirteenth centuries respectively, I show that this individual oath, called the einseiðr, started to be used as a proof in very small property disputes. From the mid-thirteenth century onwards, its use was considerably expanded to include cases where it was necessary to prove the defendant's intention or their knowledge of the circumstances of a case. I argue that this development can be explained by influence from the theological distinction between intentional and unintentional sin, as well as from theories of oath-taking in canon law, and the Roman calumny oath.
\end{abstract}

Keywords: oath, procedure, law, church law, Canon law, right, intention

In medieval Europe it was common to use oaths as proof in legal cases. These oaths were usually sworn with a number of oath-helpers, meaning people who swore together with the defendant and guaranteed the veracity of their claim (Engelmann 1928, 155-6; Helmholz 1983). While this practice of judicial oathtaking began to wane in most of Europe during the High Middle Ages, ${ }^{1}$ it persisted through the Middle Ages and into early modernity in Norway, where the practice was regulated in detail in statutory law books. Examining the regulation in these law books is useful when seeking to understand the medieval self, because although judicial oaths were usually sworn in groups, they could also, under certain

1 The reason for this seems to have been the rise of a procedural system based on Roman and canon law, used in both ecclesiastical and secular courts, in which a judge examined witnesses and written documents and weighed this evidence before coming to a conclusion (van Caenegem 1991).

*Ole-Albert Rønning Nordby, University of Oslo

๑ Open Access. (C) 2020 Ole-Albert Rønning Nordby, published by De Gruyter. (cc) BY-NC-ND This work is licensed under a Creative Commons Attribution-NonCommercial-NoDerivatives 4.0 International License. https://doi.org/10.1515/9783110655582-009 
circumstances, be sworn by the defendant alone. In the following, I will use the law books of high medieval Norway, and the way in which they regulate individual oath-taking, to analyze how, why, and to what extent medieval law accommodated and valued individual agency. In doing so, I will also show that the role of the self in Norwegian law was dramatically expanded in the High Middle Ages, largely as a result of influence from canon and Roman law.

In doing so, I will re-examine and deconstruct a categorization which has been common, albeit not universal, in the historiography of the medieval self. Two distinct but complementary ways of understanding the self are especially relevant here. On the one hand, the self can be understood politically, in the sense that individuals were increasingly perceived as having certain essential rights, such as the right to property or to participation in government. This political variety of individualism has been studied most notably by Walter Ullmann, who traces the idea of the citizen back to the thirteenth and fourteenth centuries and connects it to the rediscovery of the political philosophy of Aristotle (Ullmann 1967). On the other hand, the self could be viewed more abstractly, as what Colin Morris has called "self-awareness and self-expression, (. . .) the freedom of man to declare himself without paying excessive attention to the demands of convention or the dictates of authority" (Morris 1995, 7). Here, the emphasis would not be on the individual as a bearer of rights but on the individual as a person able to stand out against the collective social structures surrounding them. Morris argues that the intellectual ferment of the twelfth century was the beginning of a growing sense of importance of the self, a "discovery of the individual” (Morris 1995). This dichotomy between individualism as political right, and individualism as personal expression, has been pervasive in the historiography of the self, notably also in the Scandinavian historiography, as exemplified by the influential work of Sverre Bagge (Bagge 1998, 22-32).

In this chapter, I will seek to deconstruct this dichotomy by analyzing the agency of individuals in medieval legal procedure, looking at how the Norwegian medieval laws regulate individuals swearing oaths in legal procedure. Usually, judicial oaths would be supported by oath-helpers, who guaranteed that to the best of their knowledge, the statements of the principal oath-taker were true. In medieval and early modern Norwegian law, oaths could be sworn with two, five, or eleven oath-helpers, depending on the severity of the case, but the number of oath-helpers was different, and often higher, elsewhere in Europe. The severity of the case also determined whether the defendant could pick their oath-helpers freely, in which case they only had to have reached the age of majority, or whether the oath-helpers were selected from a pool of people nominated by 
defendant and plaintiff together, in which case legal status, impartiality, and past convictions of perjury set limits on who could be oath-helpers. ${ }^{2}$

However, as we have seen, not all oaths required oath-helpers. The einseiðr, or single oath, could be sworn by the defendant alone, and in the appropriate cases it was just as valid as a legal proof as oaths sworn with oath-helpers. The einseiðr was therefore a legal institution which allowed for considerable individual agency in the medieval legal procedure. Because oaths were a sufficient proof, meaning that the oath in itself was enough to settle a case conclusively in the oath-taker's favor (Engelmann 1928, 155-6), the einseiðr in effect allowed a defendant to unilaterally reject a legal accusation. Analyzing when the einseiðr was permissible, then, can grant insights into how the self could interact with the law, and what room for manoeuvre individuals were permitted.

\section{Sources}

I will base this analysis on three law books from medieval Norway. First, the Gulapingslög, which was a provincial law for the western region of Norway. As it has come down to us, the law contains multiple chronological layers of regulation which have been compiled into one law book. The earliest extant fragment of this compilation probably dates to around 1200, but the only complete manuscript, Codex Rantzovianus, or DonVar $1374^{\circ}$, is younger, dating to around 1250 (Rindal 1993, 15, 18). It is not uncommon to argue that the law book as we know it is much older than this, with some scholars arguing that it was written down as early as the first half of the eleventh century (Rindal 1993, 9-12; Nedkvitne 2004, 75-6). However, given that we lack any extant examples of vernacular writing from this period, and that the extant fragments and manuscript are much younger, I am hesitant to date the compiled Gulapingslög to much earlier than the late-twelfth century, although parts of the text are clearly older.

My second main source will be the Frostapingslög, which was a provincial law for the region of Trøndelag. The extant version of the law was most likely enacted in 1260, but like the Gulapingslög it also contains several chronological layers. We know, for example, that it was heavily revised in the mid-twelfth century, as I will discuss later in this chapter. The Frostapingslög is not extant

2 Hamre 1958; Næss 1991; Rønning Nordby 2018, 113-53. The medieval Norwegian law books also allowed women to swear oaths and to function as oath-helpers. There seems to have been a principle that when a woman was the main defendant, her oath-helpers would also have to be women, and vice versa (Rønning Nordby 2018, 146-9). 
in any complete medieval manuscripts, but rather in paper copies of Codex Resenianus, which burned in 1728 , as well as in some small medieval fragments (Hagland and Sandnes 1994, xxvi, xxxi).

Finally, I will use the Landslög, which supplanted the earlier provincial laws and was valid in the entire Norwegian kingdom, and which was enacted by King Magnús VI (r. 1263-1280) in 1274. Unlike the earlier provincial laws, the Landslög comes down to us in numerous manuscripts, due to the fact that the law was in use for centuries after its enactment. Thirty-nine manuscripts from the period between 1275 and 1400 contain the entire law book, which can also be found in some two hundred fragments (Horn 2016, 4-5). Although there are significant differences between these manuscripts, as a new critical edition of the law has shown (Rindal and Spørck 2018), the differences in content is not major enough as to alter the argument of this chapter. ${ }^{3}$

The provincial laws of the Gulaping and the Frostaping had sections at their beginnings dealing with spiritual and ecclesiastical matters. These so-called church laws were inspired by learned canon law but also had a strong element of customary law. ${ }^{4}$ In the Frostapingslög, the einseiðr is very common in the church law, but we cannot track whether this trend continued in the Landslög, because the latter does not have a section on church law. The reason for this was a conflict between Magnús VI and Archbishop Jón of Nidaros. King Magnús wanted his law book to include a section of church law, as previous Norwegian law books had done, while the archbishop was opposed to this because he denied that the crown had any jurisdiction over matters of church law, which he saw as belonging exclusively to the Church (Sunde 2005, 125). The compromise was to enact Magnús's law without the traditional first section regulating spiritual and ecclesiastical affairs. ${ }^{5}$

Analyzing the einseiðr from the perspective of normative legal texts is a necessity, because there is very little evidence for legal practice surviving from the period prior to the late Middle Ages, and as far as I am aware, none of these legal records deal with the einseiðr explicitly. However, this normative

3 Of course, the large number of extant manuscripts transmitting the Landslög also raises the question of similar variation between manuscripts of the earlier provincial laws. We know that such variation existed; there are significant differences between the paper copies of Codex Resenianus and other fragments containing the Frostapingslög. However, given that so few witnesses to the provincial laws survive, we cannot be certain about the magnitude of manuscript variation.

4 For a thorough discussion of Norwegian church law and the ways in which it was inspired by canon law, see (Landro 2010).

5 Archbishop Jón also enacted his own book of church law, but it contains few rules regulating oath-taking and I will therefore not use it here. 
perspective is valuable precisely because it allows us to investigate perceptions of individual agency and the self among the elite of thirteenth-century Norway.

\section{The Einseidr in the Provincial Laws}

One of the most curious features of the einseiðr in Norwegian law is the way in which it grew in prominence. In the Gulapingslög the einseiðr is rare. It is only mentioned in one example of a case, where the oath can be used to deny very small debts, at the value of one eyrir (Den ældre Gulathings-Lov 1846, ch. 23): a sum which could normally be exchanged for small goods like shoes, clothes, and firewood (Gullbekk 2009, 235-9). We find the same rule in the Frostapingslög and the Landslög as well (Den ældre Frostathings-Lov 1846, ch. 5:42; Nyere Lands-Lov 1848 , ch. 8:2), but in these two later law books, the einseiðr is applied to other circumstances as well. The very limited application of this oath in the Gulapingslög therefore suggests that sometime prior to the year 1200 (we cannot be certain when), a purgation oath sworn by the principal alone had been established as a mode of proof in Norwegian law, albeit a marginal one, used in very specific cases having to do with denying economic claims.

The Gulapingslög also tells us that, unlike other judicial oaths, which had to be sworn in a church with elaborate rules for how oath-helpers and witnesses should be summoned, the einseiðr could be sworn anywhere and at any time, so long as the oath-taker had a book upon which to swear (Den ældre GulathingsLov 1846, ch. 135). In disputes over very low amounts, it must have seemed unreasonable and impractical to mobilize a local community to participate in and observe ordinary oaths of denial. It would have required too much preparation, in the form of summoning and selecting oath-helpers, and too much of an elaborate ritual. In these small cases, where there was little economic value or social status at stake, setting all those gears in motion would have been overkill. Allowing a defendant to swear and deny an accusation without the support of oath-helpers, and without an elaborate ritual, provided such a remedy.

To some extent, the application of the einseiðr in the Frostapingslög seems to build directly on the principle established in the Gulapingslög that the einseiðr should only be used in conflicts over limited value. When the oath is applied to property disputes in the Frostapingslög, the property in question is always of low value. In addition to the rule governing debt denial, which we find in all the major medieval Norwegian law books, we can read that property from shipwrecks could be claimed with the einseiðr by the person who owned the land onto which the wreck had drifted, if the goods were worth less than 
three aurar (plural of eyrir). A value above that amount required the lýrittareiðr, sworn with two oath-helpers (Den ældre Frostathings-Lov 1846, ch. 2:35). A similar but much more vague rule deals with the intention to damage property. Here, the lyrittareiðr is seen as the most natural way to deny one's guilt, but the einseiðr should be used when the case was less serious (Den ældre FrostathingsLov 1846, ch. 4:37). Thus, the application of the einseiðr in the Frostapingslög does provide some support for the notion that the oath could have entered into the procedural system through debt denial. Once it had a legitimate role, it could then be applied to other similar disputes where there was little of material value at stake.

However, unlike the Gulapingslög, the Frostapingslög does not apply the einseiðr only to property disputes. Arguably, the most striking feature of the einseiðr as it appears in the Frostapingslög is its very prominent position in the church law. The church laws were separate sections of the Norwegian medieval law books which dealt with ecclesiastical and spiritual matters. The church law can be found in the second section of the Frostapingslög, and here the einseiðr seems to be the default mode of proof, as it figures in cases which seem relatively casual, as well as those having to do with life and death, salvation and damnation. On the less serious end of the scale, we find that the einseiðr can be used to deny things like refusal to help move corpses, as well as a number of offenses involving holy days, such as not coming to mass or employing someone to work. The oath can also deny knowledge that a holy day was taking place, if one was caught working on that day. We also find the einseiðr applied to more serious cases having to do with perjury, marriage, and even infanticide: a midwife could swear by herself, on behalf of a householder charged with infanticide, that a newborn infant had not been exposed but was stillborn, and the householder himself could singlehandedly deny that if a child had been exposed, it did not happen at his command (Den ældre Frostathings-Lov 1846, ch. 2:15, 28, 29, 32). Even when it comes to one of the Church's most important sources of income, the tithe, the Frostabingslög allows for the einseiðr as a satisfactory proof. The amount of tithe paid by a household would, of course, depend on the economic output of that household, but if a householder were accused of not saving up for the eventual payment of tithe, he could "læggi fram slikt er hann uil oc sanne með eiði sinum" (pay what he wants and prove with his oath) (Den ældre FrostathingsLov 1846, ch. 2:18).

By the time of the enactment of the Frostapingslög, then, the use of the einseiðr had been expanded from small property disputes to cases which had a spiritual or ecclesiastical dimension, suggesting that the Church played an important role in popularizing oaths of denial sworn without oath-helpers. Here, we also see the first signs of the einseiðr being used as proof of intent, for example when 
defendants needed to prove that they were not aware of a feast day, or that they were not aware that they had sworn falsely when they supported a legal claimant as oath-helpers (Den ældre Frostathings-Lov 1846, ch. 2:28). Using the einseiðr to prove inner mental states in this way would become an important feature of how this oath was applied after the enactment of the Landslög in 1274.

\section{The Landslög and Intent}

Like the provincial laws which it supplanted, the Landslög applies the einseiðr to economic disputes of low value (Nyere Lands-Lov 1848, ch. 7:12, 18, 8:12). Where the Landslög departs from the earlier laws is in the systematic use of the einseiðr in those instances in which the case rested on knowledge that is in some way exclusive to the defendant, which we saw the beginning of in the church law of the Frostaping. A rule which is new to the Landslög holds that an indebted man who has no property can swear the einseiðr to prove that he shall pay his creditor as soon as God gives him the opportunity (Nyere Lands-Lov 1848, ch. 8:5). Debt is also the issue in the rule dealing with circumstances where a person has died and his or her heir faces a claim from the deceased's creditor. The Landslög adopts the rule from the Gulapingslög (Den ældre Gulathings-Lov 1846, ch. 38) which says that if an heir is to deny such a debt, he or she must deny knowledge of it, so as not to swear on the dead's behalf, "En erfingi skal penna eið sueria (. . .) at eigi uar su skulld sua at ek uissa. pa uinnr hann firir sitt briost en eigi hins dauða" (but the heir (. . .) shall swear that he did not know about the debt. Then he swears for his own chest, and not on behalf of the deceased) (Nyere Lands-Lov 1848, ch. 8:6). We see a similar concern for what knowledge the einseiðr should reflect in cases having to do with damage to property caused by animals. When a mare was killed by a stallion or a dog bit livestock (Nyere Lands-Lov 1848, chs. 7:35, 38), the owners of these animals could use the einseiðr to deny any knowledge, and therefore any culpability, of the damage done. The rules specify that the oath-taker should swear only to his or her own conscience (samviska), in the first case, and his or her knowledge (vitend), in the latter. In both cases, then, the oath-taker seems to be swearing only to the content of his or her own internal mental state.

We find a similar example in a rule dealing with the sheltering of outlaws, and specifically those outlawed for killing at an assembly. Doing so would lead to outlawry, which normally would imply that the tylftareiðr, the oath of twelve, sworn with eleven oath-helpers, was necessary to deny the accusation. However, the einseiðr could be used to prove that the defendant did not shelter the outlaw willingly (Nyere Lands-Lov 1848, ch. 4:8) - that he was a úvísavargr, the technical 
term used in medieval Norwegian law for those who were unaware of the specific circumstances which made their actions illegal (Hertzberg 1895, 680). Thus, we see that the einseiðr, the purgation oath which was easiest to swear, could substitute for the largest and most complicated purgation oath when the matter to be decided concerned the defendant's intent.

\section{Inspiration from Theology and Canon Law}

What, then, inspired this growing emphasis on intent and individual agency in legal procedure? Around the turn of the twelfth century, the bishop and theologian Anselm of Canterbury introduced a distinction between intentional and unintentional sin, and this theological innovation was quickly adopted and developed in European monastic and cathedral schools (Le Goff 1981, 213-4). The consequences of this new way of thinking were far reaching, according to Jacques Le Goff, "[h]enceforth, all spiritual and moral life centered on the search for intentions, on the examination of what was voluntary and what was involuntary" (Le Goff 1981, 214). It was the content of the mind, then, which now determined the severity of sin, and given that only the individual (as well as God) could know the content of their own mind, individuals now became responsible and accountable for their own sin in a way which had tangible and practical consequences. Not long after the popularization of Anselm's distinction between voluntary and involuntary sin, yearly confessions were made mandatory by the Fourth Lateran Council of 1215. In the same period, we see a shift away from the public penances practiced in the early Middle Ages and towards more private penances. The practices were more or less the same; alms, fasting, pilgrimage, and so on, but they were no longer carried out in the view of the congregation (Arnold 2001, 61). The individual, then, was increasingly personally responsible for knowing and making amends for its own sins.

We see this emphasis on intention in the canon law of oath-taking as well. Swearing on objects, or per creaturas, was prohibited by the laws of the Church, which makes sense when we know that oaths were most likely sworn on things like weapons and rings in Viking Age Scandinavia (Riisøy 2016). However, canonists also argued that oaths could be sworn on objects if the intention of the oath-taker was to swear on that object as a reflection of the glory of God's creation. The example used by the jurists was the moon; swearing on the moon simply as an object was sinful, but swearing on it as a reflection of God was permissible (Helmholz 1996). This distinction between oaths per creaturas and what was called oath per lunam (by the moon), emphasizes the oath-takers 
internal mental state, their intention. According to the canonists, then, the content of the mind was crucial in determining whether an oath was just.

When we take ideas of church theologians and jurists into account, the growing use of the einseiðr begins to make more sense. In an intellectual climate which emphasized individual intentions and individual responsibility, it made sense to have a legal proof which made the individual solely accountable for proving legal violations. It is striking that many of the offences to which the einseiðr is applied, especially in the Frostapingslög, are legal violations which do not necessarily have a victim, but primarily puts the offending individual's salvation at risk. Working on holy days and not coming to mass are good examples. In these cases, then, it was not necessary to involve oath-helpers because the matter in question was a matter primarily of individual sin, for which the individual was primarily responsible.

The growing prominence of the einseiðr could also have been inspired more directly by the procedure which was used in canon law. We find a striking indication of this at the beginning of the Landslög, where the law deals with the cases in which it is proven that the winner of a lawsuit has carried out the litigation in some way which was not proper. How is not specified, but we might imagine transgressions ranging from procedural errors to false testimony. In these cases, the defendant - that is, the original winner of a lawsuit - had to pay a fine and the case had to be tried again. Alternatively, he could swear the einseiðr to prove "at hann hugðizt eptir retto male sokia" (that he believed that his lawsuit was just) (Nyere Lands-Lov 1848, ch. 1:6). There are clearly similarities between this oath and the calumny oath known from both Roman and canonical procedure. The point of the calumny oath was that the parties in a dispute would swear that they thought their case to be just, and that they would pursue it in an honest way (Helmholz 1996, 153-4). The major difference with the oath we find in the Landslög is that the calumny oath was supposed to be sworn prior to the trial, while this specific einseiðr is instead the result of a trial gone wrong. That said, as the rule is not found in the provincial laws, it does not seem unlikely that the compilers of the Landslög took inspiration from Romano-canonical procedure when designing this rule.

It is not difficult to imagine how ideas from both theology and canon law influenced the Norwegian procedural system. If this new way of using the einseiðr was in fact inspired by canon law, as well as theology concerned with individual intent, it makes sense that we see the first traces of it in the church law, because the educated ecclesiastical elite, who had at least some influence on the church law, would arguably have been more in touch with the development in learned law than the lay aristocracy or society at large. We know that Norwegian prelates were knowledgeable about canon law, and by extension Roman law, and it is 
likely that this knowledge would have shaped the regulation of the einseiðr. One of the first archbishops of Nidaros, Eysteinn Erlendson (d. 1188), was educated at the Abbey of St. Victor in Paris where Anselm's teachings about intentional sin had been very influential (Le Goff 1981, 214). Eysteinn was also intimately familiar with canon law, and most likely heavily involved in revisions to the church law of Trøndelag, carried out in the mid-twelfth century (Gunnes 1996, 131-6; Landau 2011; Winroth 2011; Duggan 2011). It is therefore tempting to speculate as to whether the new and expanded use of the einseiðr began with Archbishop Eysteinn, or at least in the intellectual milieu surrounding him.

As for the Landslög, we know that many of King Magnús VI's advisors, who were instrumental in shaping the law, probably had in-depth knowledge of canon law in particular (Vadum 2015, 105-6). The saga about the Icelandic bishop Árni Porláksson records that the king's chancellor, Pórir Hákonarson, knew church law very well (Árna saga biskups 1998, 35). We also know that Bjarni Loðinsson, who was the chancellor of Magnús VI's son and successor Eiríkr II, in fact possessed a doctorate in Roman law from the University of Bologna and is styled as iuris civilis professor in a peace accord between the Danish and Norwegian kings (Sällström 1957, 234). The Norwegian elite at the time of the Landslög would therefore have been knowledgeable about the legal developments taking place on the European continent during the High Middle Ages. They would have been aware of the calumny oath and its role in canon law as an oath sworn without oath-helpers as proof of the parties' good faith. We can further speculate that they would have seen the parallels between the calumny oath and the oaths used as proof in their native legal system.

\section{The Tension between Perjury and Intention}

The parallels between the einseiðr and the calumny oath do not answer the central question of why an oath sworn without oath-helpers was considered useful. Why, that is, would the legislative elite of the late-thirteenth century consider the calumny oath a worthwhile source of inspiration in the first place?

To answer this question, we should note that two of the greatest concerns underlying the legal reforms in the Landslög were, first, a new emphasis on intention as a factor of relevance in legal questions, and second, an effort to limit the risk of perjury. While intention had been an element in the earlier provincial laws as well, the concept reached much greater prominence in the Landslög, and 
the way in which this law book treats intention suggests that its legal meaning had to be thoroughly explained:

Uaða uerk eru með skynsemd greinande. með huerium hætte er pau kunnu til falla. pui at $\mathrm{i}$ allum stoðum. peim sem menn skolu ser til parfuenda vinna eða monnum til parfligra luta lið at ueita. pa eru pesse uaða uerk meir uirðande en hin er engi nauðsyn drægr til nema galoysi oc mikit stamsyni.

(Nyere Lands-Lov 1848, ch. 4:13)

[It should be carefully explained how accidental harm can occur. Because when people do something necessary, or help others do useful things, then accidental harm should be judged more mildly than if it is not caused by necessary circumstances, but by carelessness and foolishness.]

(My translation)

The chapter establishes that when people are hurt in useful endeavours - for example, when a man is killed by accident while chopping wood with another - this was to be punished more leniently than when a man is killed due to some frivolous action, like throwing a spear over a roof (Nyere Lands-Lov 1848, ch. 4:13). The central points, then, are first of all that the rule treats accidental harm as its own distinct legal category, which was not the case in the earlier provincial laws, and second that it distinguishes between different kinds of accidental harm, in accordance with precepts of Roman and canon law (Sunde 2005, 151-2). It is also striking that the rule is so methodical, in a law book which so often treats matters with extreme brevity; intention is introduced and described with detailed examples and counter-examples which clearly suggest that the law is dealing with something new or otherwise not inherently obvious to its readers.

At the same time, the Landslög sought to limit perjury. This is apparent in most of the changes to judicial oath-taking which occur between the provincial laws and the new law book. For example, the Landslög demands that oaths be sworn with a much greater proportion of oath-helpers the defendant could not pick freely and who had knowledge about the case they were swearing to, thus making it more difficult for the defendant to seduce the oath-helpers into a false oath (Nyere Lands-Lov 1848, ch. 9:13). The reason for this anxiety about perjury must have been both spiritual and political, as we can glean from other sources. St. Augustine, arguably one of the most influential thinkers during the Middle Ages, wrote that, "Swearing is a narrow ledge, perjury a precipice" (Augustine 1992, serm. 180.184). The risk of swearing falsely, and thereby falling off the edge into eternal damnation, was ever-present. The Norwegian Book of Homilies, a collection of sermons in Old Norse from the end of the twelfthcentury, echoes this sentiment and calls perjury one of the "main sins" (hofuðsyndir) (Indrebø 1966, 35). Furthermore, the treatise on morality and good governance from the middle of the thirteenth century called the King's Mirror (Konungs skuggsjá) sees perjury as a symptom of political division and weak 
kingship. Once there was more than one king, writes the anonymous author, the realm would be divided, and petty kings would protect criminals from punishment by swearing and testifying falsely on their behalf (Konungs skuggsjá 1945, 53).

These two considerations, intention and perjury, together made it useful to apply the einseiðr in a new and unprecedented way. Alan Watson has argued in his account of the medieval reception of Roman law that:

systems of customary law are peculiarly susceptible to this type of borrowing from elsewhere precisely because they are notoriously lacking in precision and clarity, when a need for a rule arises it may not be found or easily found in what the people do.

(Watson 1985, 75)

If Watson is correct, we should expect the transplants into Norwegian medieval law to appear in places where the borrowing served some new function which the legislative elite (in this case, primarily Magnús VI and his advisors) thought to be useful or necessary. The dramatically expanded role of the einseiðr might be an expression of precisely this dynamic. When the new law introduced a much greater emphasis on intention, there would also have to be a corresponding legal mechanism which could prove intention. Given that the compilers of the Landslög were also concerned with the spiritual and political threat of perjury, and that they explicitly prohibited oath-helpers from swearing to that about which they had no knowledge, a mode of proof was necessary which was intimately tied to the individual, and specifically the individual's knowledge and internal mental state. In this situation, the calumny oath, a mechanism used to access the litigant's intention and good will, could have seemed useful. Furthermore, transferring it would have been easy, as an oath sworn by one of the parties alone was already part of the Norwegian procedural system, as proof in small-scale property disputes. Thus, we can imagine that, inspired by the function of the calumny oath, the compilers of the Landslög expanded the role of the einseiðr considerably in order to serve a new function which had not really motivated any earlier procedural laws.

\section{The Problem with the Einseizr as Proof of Intent}

In the aforementioned rule in the Landslög dealing with intention, we saw that the law established that bodily harm would be treated in a distinct way if it were unintentional and useful - for example, if a man killed another with his axe while they were out in a forest chopping wood. The problem is that this rule firmly establishes what it would take to prove that such manslaughter was unintentional, and it is not an einseiðr but the séttareiðr, the oath sworn with 
five oath-helpers. Thus, it seems difficult to sustain the idea that the einseiðr was expanded for the purpose of serving as proof in cases dealing with intention when the very rule that introduces intention as an important legal concept does not demand the einseiðr as proof.

Yet this is not an insurmountable problem. Note that the rule in question deals with killing, and that it grants a defendant charged with a killing the opportunity to deny his or her intention to kill. This was, of course, an extremely serious matter. The rule is not clear at all on the question of what would happen if the defendant did not swear the oath, or failed in doing so, but it seems likely that, in these cases, a fatal accident would then be considered a homicide, and the perpetrator would have to pay not only full compensation to the victim's heir but also the fine to the king which compensated him for the loss of a subject (Nyere Lands-Lov 1848, ch. 4:2). It is also worth pointing out that, while all the medieval Norwegian legal texts apply the single purgation oath liberally to disputes over property, family, and spiritual matters, it is never applied to violence, with such rigor that it makes sense to interpret the trend as a principle. In this light, the rules in the provincial laws on infanticide discussed above are also particularly interesting. The Gulapingslög calls infanticide morð, or murder (its technical meaning is concealed homicide), thus clearly construing it as a violent crime, but we do not find this framework applied to the exposure of infants in the Frostapingslög. Where a transgression is clearly and explicitly coded as violent, then, many oath-helpers are necessary to deny the accusation. When no such coding is present, the einseiðr is acceptable as proof.

Additionally, there was an element of royal financial interest which also came into conflict with the high-minded ideals of the legal reforms. The crown was entitled to fines only when the harm caused was intentional (Nyere LandsLov 1848, ch. 4:13) - fines which, in cases of homicide, were substantial - and thus it was not in the crown's interest to make it easy for a defendant to escape a charge of intentional homicide. Fines were perhaps the most important source of royal revenue in the late-thirteenth and early fourteenth centuries. Kåre Lunden argues that the crown's income from fines was at least the size of its income from taxes, and probably much larger (Lunden 1976, 305-6, 309). It would therefore appear that, when regulating the legal distinction between intentional and unintentional bodily harm and applying the mode of proof used to establish this distinction, established custom and royal interests played off of one another. Despite their learned influences, King Magnús and his advisors simply could not permit the einseiðr to be used to prove a lack of intention in cases of killing or serious injury, even though this would be more in keeping with the principle used to apply the einseiðr elsewhere. Doing so would not 
only go against the norms which lay at the very foundation of the legal system but also put the crown's income from fines in peril.

\section{The Einseidr and the Medieval Self}

So far, I have showed that the einseiðr was first used as a flexible and relatively spontaneous mode of proof in property disputes with small values at stake. It also appears that it was first used specifically to deny debt, as in the Gulapingslög, before being applied to low-value property disputes more generally in the later law books.

Towards the middle of the thirteenth century, legislators learned in canon law gave the einseiðr a new role. We see the beginnings of this development in the Frostapingslög, where the oath was by far the most common mode of proof in the section of the law dealing with the Church and spiritual matters. Here, the einseiðr is used to settle not only small disputes but also serious transgressions and matters of considerable social significance, such as infanticide, marriage, and perjury.

In the Landslög, the einseiðr was used not only in small-scale property disputes, as in the provincial laws, but also, and more importantly, to prove a defendant's intention - for example, his or her ignorance of a guest's outlaw status or claim that a case had been brought in good faith. The crown's growing interest in intention as a means of legal differentiation, coupled with its fear of perjury, made the einseiðr useful. As in the property disputes, the application of the einseiðr to cases resting on intention is pragmatic, but it is pragmatism in service of ideological, religious, and legal principles rather than procedural expediency. However, we have also seen that there were limits to how far these principles could go. It was clearly out of the question that a defendant could use the einseiðr to prove intention in cases of homicide or bodily harm, when large fines to the crown were at stake.

At the outset of this chapter, I set out to deconstruct a dichotomy often found in the traditional historiography of medieval individualism, namely, between individualism as political and legal rights, in the vein of Walter Ullman, and individualism as self-expression, in the vein of Colin Morris. The regulation of the einseiðr does not seem to fall comfortably into either of these categories. Intuitively, any study which uses normative legal texts as its main sources must concern itself to some extent with the legal and political aspect of individualism. This is after all a lot of what a legal text deals with, who has the right to what? When the issue at hand is the growing prominence of the einseiðr, we are also indeed dealing with a question of rights, at least in part, the right of the individual to settle a case by swearing an oath without the support of oath-helpers. In this light, it is possible to 
see the development of oath-taking in thirteenth-century Norway as expressing a growing, if still marginal, legal and political individualism.

That said, thinking about the self's role in the einseiðr solely from the perspective of rights is not enough. In doing so, we ignore the fact that a premise for the expanded rights of individuals to swear oaths is the idea that the knowledge of individuals is important and valuable. The laws assume that individuals have knowledge about themselves, and that they are able to express this knowledge in a way which is relevant and useful in a legal procedure. Such an idea seems much more in line with the "freedom of man to declare himself," proposed by Colin Morris, than with individualism as an expression of political rights. Swearing a purgation oath without oath-helpers is clearly a kind of individual right, but only in the context of an understanding of the individual as self-aware, and as able to express that self-awareness in a structured way. As such, my analysis has shown that the individual's place in society is not easily, or perhaps even productively, divided into categories which adhere to the taxonomy of modern scholarship. If we are to understand how the role of the individual changes in medieval Norwegian law, and in medieval Europe in general, we must assume that this change manifests on multiple levels, simultaneously and in relation to each other. Self-awareness and rights seem to go together, at once dependent upon and playing off of one another.

\section{References}

\section{Primary Sources}

Augustine. 1992. Sermons. Trans. Edmund Hill. Ed. John E. Rotelle. Sermons, III/5 on the New Testament. New Rochelle, NY. 148-83.

Árna saga biskups. 1998. Ed. Guðrún Ása Grímsdóttir. Íslenzk Fornrit, 17. Reykjavík. 1-207. Den ældre Frostathings-Lov. 1846. In Norges gamle love indtil 1387, 1. Ed. P. A. Munch, Rudolf Keyser, and Chr. Grøndahl. Christiania. 119-258.

Den ældre Gulathings-Lov. 1846. In Norges gamle love indtil 1387, 1. Ed. P. A. Munch, Rudolf Keyser, and Chr. Grøndahl. Christiania. 1-118.

Holm-Olsen, Ludvig, ed. 1945. Konungs skuggsjá. Oslo. Indrebø, Gustav, ed. 1966. Gamalnorsk Homiliebok, Cod. AM. 619 4. Oslo.

Nyere Lands-Lov. 1848. In Norges gamle love indtil 1387, 2. Ed. P. A. Munch, Rudolf Keyser, and Chr. Grøndahl. Christiania. 1-178.

Rindal, Magnus and Bjørg Dale Spørck, eds. 2018. Kong Magnus Lagabøtes landslov. Norrøn tekst med fullstendig variantapparat. Norrøne tekster, 9. Oslo. 


\section{Secondary Sources}

Arnold, John H. 2001. Inquisition and Power, Catharism and the Confessing Subject in Medieval Languedoc. Philadelphia.

Bagge, Sverre. 1998. “Innledning: Individet i den europeiske kulturtradisjon.” In Det europeiske menneske, Individoppfatninger fra middelalderen til i dag. Ed. Sverre Bagge. Oslo. 9-35.

Duggan, Anne J. 2011. "Eystein and the World of the Learned Law." In Archbishop Eystein as Legislator, The European Connection. Ed. Tore Iversen. Trondheim. 23-56.

Engelmann, Arthur. 1928. A History of Continental Civil Procedure. Trans. Robert Wyness Millar. 2nd ed. The Continental Legal History Series, 7. London.

Gullbekk, Svein H. 2009. Pengevesenets fremvekst og fall i Norge i middelalderen. Copenhagen.

Gunnes, Erik. 1996. Erkebiskop Øystein: Statsmann og kirkebygger. Oslo.

Hagland, Jan Ragnar and Jørn Sandnes. 1994. “Om lova og lagdømmet.” In Frostatingslova. Ed. Jan Ragnar Hagland and Jørn Sandnes. Oslo. ix-xlv.

Hamre, Lars. 1958. “Edgärdsman. Norge.” In Kulturhistorisk leksikon for nordisk middelalder, Vol. III. Ed. Finn Hødnebø et al. Oslo. Cols. 492-9.

Helmholz, Richard H. 1983. "Crime, Compurgation and the Courts of the Medieval Church." Law and History Review 1.1: 1-26.

Helmholz, Richard H. 1996. The Spirit of Classical Canon Law. The Spirit of the Laws. Athens and London.

Hertzberg, Ebbe. 1895. "Glossarium." In Norges gamle love indtil 1397, vol. 5. Ed. Gustav Storm and Ebbe Hertzberg. Christiania. 57-834.

Horn, Anna Catharina. 2016. Lov og tekst i middelalderen, Produksjon og resepsjon av Magnus Lagabøtes landslov. Göteborgsstudier i nordisk språkvetenskap, 26. Gothenburg.

Landau, Peter. 2011. "Canon Law in the Periphery of Europe, The Example of Eystein." In Archbishop Eystein as Legislator, The European Connection. Ed. Tore Iversen. Trondheim. 57-72.

Landro, Torgeir. 2010. "Kristenrett og kyrkjerett: Borgartingskristenretten i eit komparativt perspektiv." Unpublished doctoral dissertation, University of Bergen.

Le Goff, Jacques. 1981. The Birth of Purgatory. Trans. Arthur Goldhammer. Chicago.

Lunden, Kåre. 1976. Norge under Sverreætten, 1177-1319. Norges historie, 3. Oslo.

Morris, Colin. 1995. The Discovery of the Individual, 1050-1200. Medieval Academy Reprints for Teaching, 19. Toronto.

Nedkvitne, Arnved. 2004. The Social Consequences of Literacy in Medieval Scandinavia. Utrecht Studies in Medieval Literacy, 11. Turnhout.

Næss, Hans Eyvind. 1991. "Mededsinstituttet: En undersøkelse av nektelsesedens utbredelse og betydning i norsk rettsliv på 1600-tallet.” (Norsk) Historisk Tidsskrift 70.2: 179-201.

Riisøy, Anne Irene. 2016. "Performing Oaths in Eddic Poetry: Viking Age Fact or Medieval Fiction?" Journal of the North Atlantic 8: 141-56.

Rindal, Magnus. 1993. “Innleiing.” In Den Eldre Gulatingslova. Ed. Bjørn Eithun, Magnus Rindal, and Tor Ulset. Norrøne tekster, 6. Oslo. 7-30.

Rønning Nordby, Ole-Albert. 2018. "The Judicial Oath in Medieval Norway, Compurgation, Community and Knowledge in the Thirteenth Century." Unpublished doctoral dissertation, University of Oslo. 
Sunde, Jørn Øyrehagen. 2005. Speculum Legale - Rettsspegelen, Ein introduksjon til den norske rettskulturen si historie i eit europeisk perspektiv. Bergen.

Sällström, Åke. 1957. Bologna och Norden intill Avignonpåvedömets tid. Lund.

Ullmann, Walter. 1967. The Individual and Society in the Middle Ages. London.

Vadum, Kristoffer. 2015. "Bruk av kanonistisk litteratur i Nidarosprovinsen ca. 1250-1340." Unpublished doctoral dissertation, University of Oslo.

van Caenegem, Raoul C. 1991. Legal History, A European Perspective. London.

Watson, Alan. 1985. The Evolution of Law. Baltimore, Maryland.

Winroth, Anders. 2011. “Decretum Gratiani and Eystein's Canones Nidrosienses.” In Archbishop Eystein as Legislator: The European Connection. Ed. Tore Iversen. Trondheim. 73-86. 
